\title{
Induction and enhancement of the novel marine-derived Alternaria tenuissima KM651985 laccase enzyme using response surface methodology: Application to Azo and Triphenylmethane dyes decolorization
}

\author{
Abeer A. Abd El Aty*, Eman R. Hamed, Ahmed A. El-Beih, Ahmed I. El-Diwany \\ Chemistry of Natural and Microbial Products Dept., National Research Centre, Dokki, Giza, Egypt.
}

\begin{tabular}{l} 
ARTICLE INFO \\
\hline Article history: \\
Received on: 04/01/2016 \\
Revised on: 05/02/2016 \\
Accepted on: $13 / 03 / 2016$ \\
Available online: $30 / 04 / 2016$ \\
\hline Key words: \\
Alternaria tenuissima \\
KM651985, Response \\
Surface Methodology, \\
Plackett-Burman Design, \\
optimization, decolorization.
\end{tabular}

\section{INTRODUCTION}

Laccases (benzenediol: oxygen oxidoreductases, EC 1.10.3.2) are blue multicopper oxidases which catalyze the oxidation of an array of aromatic substrates with the reduction of molecular oxygen to water (Giardina et al., 2010). Laccases are known for their importance in the development of efficient biotechnology processes (degradation of different recalcitrant compounds, delignification of lingocellulosics, paper bleaching, bioremediation, dye decolorization and sewage treatment, etc) (Rodriguez et al., 2005; Osma et al., 2010; Shervedani and Amini, 2012). The majority of laccases are often found in whiterot fungi and higher plants such as the varnish tree Rhus vernicifera (Morozova et al., 2007). The production of laccases

\footnotetext{
* Corresponding Author

E. mail: aabass44[at]yahoo.com

Tel. \& Fax./ +2-(02)33387681-33371433-33371499.
}

from new sources at low cost is very essential from industrial point of view. One of these sources might be the marine derived fungi that have been adapted to live in the marine environment. Fungi obtained from marine sources colonizing twigs, mangrove leaves, sea grasses and wood pieces are able to produce lignin degrading enzymes, and they are mainly belong to ascomycetes and a very few to basidiomycetes (Pointing and Hyde, 2000; Bucher et al., 2004). Filamentous fungi growing under such marine conditions have many advantages, that they adapted to grow under alkaline conditions ( $\mathrm{pH}$ of seawater ranges from 7.5 to 8.2 ) and saline conditions (from 10 to $34 \mathrm{ppt}$ ). Such lignin degrading enzymeproducing fungi showed different application in bioremediation of lignin-based derivatives and colored industrial pollutants such as pulp mills, tanneries, molasses-based distilleries, synthetic dyes and the textile mills (Bartlett, 1971). Up to date, the applications of laccase on a commercial scale is restrained by the low productivity in microbial fermentation. 
For this reason, it is useful to optimize the medium composition for production of laccase by fungi. Statistical experimental designs are known useful tools for medium optimization to screen the main variables rapidly from a multivariable system. The statistical experimental designs have many advantages, including more advanced results with less development time and less overall costs. Plackett-Burman (PB) and response surface methodology (RSM) have been successfully applied in the improvement of the medium conditions of laccase product from different microorganism such as Pleurotus sp. and Mycena purpureofusca (Bhattacharya et al., 2011; Zhang et al., 2012).

The main goal of the present paper was to find a new source for laccase production tolerant to saline and alkaline conditions. Optimization of medium composition for high laccase production using statistical experimental designs. The application of crude culture filtrate of laccase producing fungus to decolorize two chemically different synthetic dyes.

\section{MATERIALS AND METHODS}

\section{Chemicals}

Guaiacol (2-methoxyphenol) and veratryl alcohol were purchased from Fluka Company. 2,2'-Azino-bis(3ethylbenzothiazoline-6-sulphonic acid) diammonium salt (ABTS) was obtained from MP Biomedicals, LLC.29525 Fountain Pkwy, Solon, OH 44139,USA., Congo Red, Crystal violet were purchased from Sigma Company, Germany. Wheat bran was purchased from local market.

\section{Microorganism and maintenance}

The marine-derived fungal isolate used in this study was locally isolated from samples of marine decayed wood collected from Port-Said Governorate, Egypt, 2014 (Abd El Aty et al., 2015). Stock cultures were maintained on malt extract agar (MEA) slant at $4{ }^{\circ} \mathrm{C}$ and sub-cultured every 3 months. The medium is composed of biomalt $20 \mathrm{~g} / \mathrm{L}$, agar $15 \mathrm{~g} / \mathrm{L}, 800 \mathrm{~mL}$ sterile sea water and $200 \mathrm{~mL}$ distilled water (Höller et al., 1999).

\section{Identification of the marine-derived filamentous fungal isolate}

From previous screening experiments, one selected isolate having the ability to produce laccase was used. It was identified morphologically in the department of Chemistry of Natural and Microbial Products, National Research Centre according to (Pitt and Hocking, 1985; Kohlmeyer and Kohlmeyer, 1979) to be Alternaria tenuissima. This was further confirmed using molecular taxonomy tools

Molecular identification of the fungus was based on their internal transcribed spacer ribosomal DNA (ITS-rDNA) sequences. Mycelia were collected by centrifugation and DNA was extracted by using protocol of Gene Jet Plant genomic DNA purification Kit (Thermo \# K0791). PCR was made by using Maxima Hot Start PCR Master Mix (Thermo\# K0221), and PCR clean up to the PCR product made by using GeneJET ${ }^{\text {TM }}$ PCR Purification Kit (Thermo\# K0701) in Sigma Company of
Scientific Services, Egypt (www.sigma-co-eg.com). Finally, sequencing to the PCR product performed in GATC Company, German, by use ABI 3730xl DNA sequencer with the new 454 technology.

Purified DNA was subjected to PCR amplification using a pair of ITS1 (5'-TCC GTA GGT GAA CCT GCG G-3') and ITS4 (5'-TCC TCC GCT TAT TGA TAT GC-3') primers for ITSrDNA amplification (White et al., 1990). Sequence data was analyzed in the Gene Bank database by using the BLAST program available on the National Center for Biotechnology Information website (www.ncbi.nlm.nih.gov). The unknown sequence was compared to all of the sequences in the database to assess the DNA similarities (Altschul et al., 1997). Alignment and molecular phylogeny were evaluated using Bio Edit software.

The nucleotide sequence of the marine-derived fungal isolate determined in this study has been deposited in the GenBank under the accession number (KM651985).

\section{Media and culture conditions for laccase production}

Laccase producing ability of the marine-derived fungal isolate was tested in two different liquid fermentation media; Boyd \& Kohlmeyer $(\mathrm{B} \& \mathrm{~K})$ synthetic culture medium containing $(\mathrm{g} / \mathrm{L})$, glucose 10, peptone 2, yeast extracts 1 in $50 \%$ sea water (D'Souza et al., 2006) and the natural culture medium containing, 3g/flask wheat bran without any additives. Fungus cultures were grown in $250 \mathrm{~mL}$ flasks containing $50 \mathrm{~mL}$ medium or only sea water with wheat bran medium at $28^{\circ} \mathrm{C}$ for 14 days under static conditions.

The spore suspension was prepared from a 7 days old culture grown on MEA slants prepared with seawater by adding 10 $\mathrm{ml}$ of sterile distilled water. One $\mathrm{ml}$ of the spore suspension containing about $1 \times 10^{7}$ spores $/ \mathrm{ml}$ was used as inoculum.

\section{Confirmation for laccase production (Guaiacol oxidation)}

Laccase production in liquid fermentation medium was confirmed by addition of $(0.7 \mathrm{ml})$ of culture filtrate containing about (10.16 U of crude enzyme) to Petri dish prepared with B\&K supplemented with $4 \mathrm{mM}$ guaiacol, and incubated for $24 \mathrm{~h}$. at $28{ }^{\circ} \mathrm{C}$ in dark. The production of an intense brown color around the hole containing the enzyme resulting from guaiacol oxidation was considered as a positive reaction for the presence of laccase activity.

\section{Enzyme assay}

Laccase (EC 1.10.3.2) activity was measured according to the method described by Bournnais (Bournnais et al., 1995). The principle of this method is based on the oxidation of the substrate 2,2'-azino-bis (3-ethylbenzothiazoline)-6-sulphonic acid (ABTS). The rate of ABTS oxidation was determined spectrophotometrically at $420 \mathrm{~nm}$.

The reaction mixture contained $600 \mu \mathrm{L}$ sodium acetate buffer $\left(0.1 \mathrm{M}, \mathrm{pH} 5.0\right.$ at $\left.27^{\circ} \mathrm{C}\right), 300 \mu \mathrm{L}$ ABTS $(5 \mathrm{mM})$, $300 \mu \mathrm{L}$ mycelial liquid fraction and $1400 \mu \mathrm{L}$ distilled water. The mixture was then incubated for $2 \mathrm{~min}$ at $30^{\circ} \mathrm{C}$. The absorbance was measured immediately in one-minute intervals. One unit of 
laccase activity was defined as activity of an enzyme that catalyzes the conversion of $1 \mu$ mole of ABTS per minute. The blank contained all the assay constituents except the active enzyme; it was replaced heated inactivated enzyme.

\section{Experimental designs}

\section{Plackett-Burman design (PBD)}

Plackett-Burman experimental design (Plackett and Burman, 1946) was used to evaluate the relative importance of various nutrients and inducers for the production of laccase by $A$. tenuissima KM651985 in submerged fermentation. Eleven components (Wheat bran, sucrose, glucose, peptone, ammonium tartrate, $\mathrm{CuSO} 4.5 \mathrm{H}_{2} \mathrm{O}$, phenol, guaiaol, vertryl alcohol, $\mathrm{ABTS}$, and tween 80) were selected for the study, each variable was represented at two levels, high concentration $(+1)$ and low concentration $(-1)$ as shown in Table (1).

Tested factors represented in twelve trials Plackett-Burman experimental design with the response. Each row represented a trial run and each column represented an independent variable concentrations. All experiments were carried out in duplicate and the average laccase activity was taken as the response Table (1). Plackett-Burman experimental design is based on the first order linear model:

$$
\mathrm{Y}=\mathrm{B} 0+\sum \mathrm{BiXi}
$$

$\mathrm{Y}$ is the response (laccase production), $\mathrm{B} 0$ is the model intercept and $B i$ is the variables estimates. The effect of each variable was determined by the following equation,

$$
\mathrm{E}(\mathrm{Xi})=\frac{2\left(\sum \mathrm{M}_{\mathrm{i}}^{+}-\mathrm{M}_{\mathrm{i}}{ }^{-}\right)}{\mathrm{N}}
$$

E (Xi) is the effect of the tested variable. $\mathrm{M}_{\mathrm{i}}^{+}$and $\mathrm{M}_{\mathrm{i}}^{-}$represent laccase production from the trials where the variable $(\mathrm{Xi})$ measured was present at high and low concentrations, respectively and $\mathrm{N}$ is the number of trials in Eq. (2). Statistical analysis of PBD is performed by using Design-Expert@ 8 software from StatEase, Inc. Table (2).

\begin{tabular}{|c|c|c|c|c|c|c|c|c|c|c|c|c|}
\hline \multirow[b]{2}{*}{ Trials } & \multicolumn{3}{|c|}{$\begin{array}{c}\text { Carbon sources } \\
(\mathrm{g} / \mathrm{l})\end{array}$} & \multicolumn{2}{|c|}{$\begin{array}{c}\text { Nitrogen sources } \\
(\mathrm{g} / \mathrm{l})\end{array}$} & \multicolumn{6}{|c|}{$\begin{array}{c}\text { Inducers } \\
(\mathbf{m M})\end{array}$} & \multirow[b]{2}{*}{$\begin{array}{c}\text { Laccase } \\
\text { enzyme } \\
\text { activity } \\
\text { (U/ml) }\end{array}$} \\
\hline & $\begin{array}{c}\text { Factor1 } \\
\text { A: } \\
\text { Wheat } \\
\text { bran }\end{array}$ & $\begin{array}{l}\text { Factor2 } \\
\text { B: } \\
\text { Sucrose }\end{array}$ & $\begin{array}{l}\text { Factor3 } \\
\text { C: } \\
\text { Glucose }\end{array}$ & $\begin{array}{l}\text { Factor4 } \\
\text { D: } \\
\text { Peptone }\end{array}$ & $\begin{array}{c}\text { Factor } 5 \\
\text { E: } \\
\text { Ammonium } \\
\text { tartarate }\end{array}$ & $\begin{array}{c}\text { Factor } 6 \\
\text { F: } \\
\text { Copper } \\
\text { sulphate }\end{array}$ & $\begin{array}{l}\text { Factor7 } \\
\text { G: } \\
\text { Phenol }\end{array}$ & $\begin{array}{c}\text { Factor8 } \\
\text { H: } \\
\text { Guaiaol }\end{array}$ & $\begin{array}{l}\text { Factor } 9 \\
\text { J: } \\
\text { Veratryl } \\
\text { alcohol }\end{array}$ & $\begin{array}{c}\text { Factor10 } \\
\text { K: } \\
\text { ABTS }\end{array}$ & $\begin{array}{c}\text { Factor11 } \\
\text { L: } \\
\text { Tween } 80\end{array}$ & \\
\hline 1 & $-1(5)$ & $-1(5)$ & $-1(5)$ & $+1(2)$ & $-1(0.2)$ & $+1(2)$ & $+1(1)$ & $-1(0)$ & $+1(1)$ & $+1(1)$ & $+1(0.5)$ & $7.3 \pm 0.211$ \\
\hline 2 & $-1(5)$ & $+1(10)$ & $-1(5)$ & $+1(2)$ & $+1(2)$ & $-1(0)$ & $+1(1)$ & $+1(1)$ & $+1(1)$ & $-1(0)$ & $-1(0)$ & $1.3 \pm 0.497$ \\
\hline 3 & $+1(10)$ & $+1(10)$ & $-1(5)$ & $-1(0.2)$ & $-1(0.2)$ & $+1(2)$ & $-1(0)$ & $+1(1)$ & $+1(1)$ & $-1(0)$ & $+1(0.5)$ & $45.5 \pm 2.486$ \\
\hline 4 & $+1(10)$ & $-1(5)$ & $+1(10)$ & $+1(2)$ & $-1(0.2)$ & $+1(2)$ & $+1(1)$ & $+1(1)$ & $-1(0)$ & $-1(0)$ & $-1(0)$ & $30.9 \pm 1.119$ \\
\hline 5 & $+1(10)$ & $+1(10)$ & $-1(5)$ & $+1(2)$ & $+1(2)$ & $+1(2)$ & $-1(0)$ & $-1(0)$ & $-1(0)$ & $+1(1)$ & $-1(0)$ & $6.9 \pm 3.605$ \\
\hline 6 & $-1(5)$ & $+1(10)$ & $+1(10)$ & $-1(0.2)$ & $+1(2)$ & $+1(2)$ & $+1(1)$ & $-1(0)$ & $-1(0)$ & $-1(0)$ & $+1(0.5)$ & $7.6 \pm 0.746$ \\
\hline 7 & $+1(10)$ & $-1(5)$ & $+1(10)$ & $+1(2)$ & $+1(2)$ & $-1(0)$ & $-1(0)$ & $-1(0)$ & $+1(1)$ & $-1(0)$ & $+1(0.5)$ & $6.6 \pm 0.052$ \\
\hline 8 & $+1(10)$ & $-1(5)$ & $-1(5)$ & $-1(0.2)$ & $+1(2)$ & $-1(0)$ & $+1(1)$ & $+1(1)$ & $-1(0)$ & $+1(1)$ & $+1(0.5)$ & $3.5 \pm 7.086$ \\
\hline 9 & $-1(5)$ & $+1(10)$ & $+1(10)$ & $+1(2)$ & $-1(0.2)$ & $-1(0)$ & $-1(0)$ & $+1(1)$ & $-1(0)$ & $+1(1)$ & $+1(0.5)$ & $11 \pm 1.367$ \\
\hline 10 & $+1(10)$ & $+1(10)$ & $+1(10)$ & $-1(0.2)$ & $-1(0.2)$ & $-1(0)$ & $+1(1)$ & $-1(0)$ & $+1(1)$ & $+1(1)$ & $-1(0)$ & $9.6 \pm 1.119$ \\
\hline 11 & $-1(5)$ & $-1(5)$ & $-1(5)$ & $-1(0.2)$ & $-1(0.2)$ & $-1(0)$ & $-1(0)$ & $-1(0)$ & $-1(0)$ & $-1(0)$ & $-1(0)$ & $1.5 \pm 1.492$ \\
\hline 12 & $-1(5)$ & $-1(5)$ & $+1(10)$ & $-1(0.2)$ & $+1(2)$ & $+1(2)$ & $-1(0)$ & $+1(1)$ & $+1(1)$ & $+1(1)$ & $-1(0)$ & $25 \pm 1.740$ \\
\hline
\end{tabular}

Table 1: Twelve trials Plackett-Burman experimental design with the response.

+1 and -1 represent the coded levels (high and low) of the independent variable. Tween 80 in (\%). Values of response are the mean of duplicate cultivation experiments $\pm \mathrm{SD}$.

Table 2: Statistical analysis of Plackett-Burman design.

\begin{tabular}{cccccc}
\hline Source & Sum of Squares & df & Mean Square & F-value & $\begin{array}{c}\text { P-value } \\
\text { Prob>F }\end{array}$ \\
\hline Model & 2027.88 & 9 & 225.32 & 60.02 & 0.0165 significant \\
A-Weat bran & 202.54 & 1 & 202.54 & 53.95 & 0.0180 \\
C-Glucose & 50.84 & 1 & 50.84 & 13.54 & 0.0666 \\
D-Peptone & 68.64 & 1 & 68.64 & 18.28 & 0.0506 \\
E- Ammonium tartrate & 251.17 & 1 & 251.17 & 66.90 & 0.0146 \\
F- Copper sulphate & 670.51 & 1 & 670.51 & 178.60 & 0.0056 \\
G-Phenol & 109.81 & 1 & 109.81 & 29.25 & 0.0325 \\
H-Guaiacol & 503.11 & 1 & 503.11 & 25.01 & 0.0370 \\
J- Veratryl alcohol & 95.77 & 1 & 95.77 & 20.11 & 0.0463 \\
K-ABTS & 75.50 & 1 & 75.50 & & \\
Residual & 7.51 & 2 & 3.75 & & \\
Cor Total & 2035.39 & 11 & & & \\
\hline
\end{tabular}

Std. Dev. $=1.94$, Mean= 13.06, C.V. $\%=14.84$, PRESS $=270.30$, R-Squared= 0.9963, Adj R-Squared=0.9797, Pred R-Squared= 0.8672, Adeq Precision $=24.396$ (factors L-Tween $80 \&$ B-Sucrose were removed where, Prob $>|t|=0.1000$ and 0.4620 , respectively) 


\section{Central composite design (CCD)}

Based on the results of Plackett-Burman design, the optimal significant variables for laccase production were investigated using response surface methodology of central composite design (CCD).

Table 3: Coded levels and actual values of variables, along with matrix of central composite design (CCD) showing experimental and predicted values of laccase activity.

\begin{tabular}{cccccc}
\hline & $\begin{array}{c}\text { Copper } \\
\text { sulphate } \\
(\mathbf{A}, \mathbf{m M})\end{array}$ & $\begin{array}{c}\text { Guaiacol } \\
(\mathbf{B}, \mathbf{m M})\end{array}$ & $\begin{array}{c}\text { Wheat bran } \\
\text { (C, } \mathbf{g} / \mathbf{l})\end{array}$ & \multicolumn{2}{c}{$\begin{array}{c}\text { Laccase activity } \\
\text { (U/ml) }\end{array}$} \\
\cline { 2 - 6 } & $\begin{array}{c}\text { levels } \\
\text { (values) }\end{array}$ & $\begin{array}{c}\text { levels } \\
\text { (values) }\end{array}$ & $\begin{array}{c}\text { levels } \\
\text { (values) }\end{array}$ & experimental & predicted \\
\hline 1 & $0(3)$ & $0(2)$ & $0(30)$ & 65.91 & 65.52 \\
2 & $0(3)$ & $0(2)$ & $0(30)$ & 65.63 & 65.52 \\
3 & $0(3)$ & $0(2)$ & $0(30)$ & 65.63 & 65.52 \\
4 & $0(3)$ & $0(2)$ & $0(30)$ & 65.21 & 65.52 \\
5 & $0(3)$ & $0(2)$ & $0(30)$ & 65.42 & 65.31 \\
6 & $+\alpha(4.68)$ & $0(2)$ & $0(30)$ & 53.68 & 55.17 \\
7 & $-1(2)$ & $-1(1)$ & $-1(20)$ & 44.03 & 42.51 \\
8 & $0(3)$ & $+\alpha(3.68)$ & $0(30)$ & 69.40 & 63.79 \\
9 & $-1(2)$ & $+1(3)$ & $-1(20)$ & 48.02 & 52.97 \\
10 & $-\alpha(1.32)$ & $0(2)$ & $0(30)$ & 59.34 & 57.19 \\
11 & $-1(2)$ & $+1(3)$ & $+1(40)$ & 79.04 & 82.45 \\
12 & $-1(2)$ & $-1(1)$ & $+1(40)$ & 64.16 & 63.24 \\
13 & $0(3)$ & $0(2)$ & $-\alpha(13.18)$ & 37.11 & 37.37 \\
14 & $+1(4)$ & $-1(1)$ & $-1(20)$ & 45.92 & 42.97 \\
15 & $0(3)$ & $0(2)$ & $0(30)$ & 65.21 & 65.52 \\
16 & $0(3)$ & $-\alpha(0.32)$ & $0(30)$ & 48.02 & 51.04 \\
17 & $+1(4)$ & $+1(3)$ & $-1(20)$ & 35.23 & 36.62 \\
18 & $+1(4)$ & $-1(1)$ & $+1(40)$ & 77.80 & 75.25 \\
19 & $+1(4)$ & $+1(3)$ & $+1(40)$ & 77.58 & 79.57 \\
20 & $0(3)$ & $0(2)$ & $+\alpha(46.82)$ & 91.84 & 90.92 \\
\hline$\alpha=1.682$ & & & & &
\end{tabular}

Using 3-factor-5-level central composite design (CCD) with twenty experiments, were carried out to determine the optimal values of copper sulphate (A), guaiacol (B) and wheat bran $(\mathrm{C})$ and to develop a mathematical correlation between the three significant variables and laccase activity (Y). All three variables were investigated at low level $(-1)$, zero level $(0)$ and high level $(+1)$, respectively, with $\alpha=1.682$. Codes and actual values of variables and matrix of CCD along with laccase activity of each trial are shown in Table (3).

Statistical analysis of CCD is shown in Table (4). The behavior of the system was explained by the following quadratic model equation.

$Y_{\text {(activity) }}=\beta 0+\beta_{1} A+\beta_{2} B+\beta_{3} C+\beta_{11} A^{2}+\beta_{22} B^{2}+\beta_{33} C^{2}+\beta_{12} A B+$ $\beta_{13} A C+\beta_{23} B C$

where $Y_{\text {(activity) }}$ was the predicted production of laccase $(\mathrm{U} / \mathrm{mL})$, $\beta 0$ intercept, $\beta 1, \beta 2$ and $\beta 3$ linear coefficients, $\beta 11, \beta 22$ and $\beta 33$ quadratic coefficients and $\beta 12, \beta 13$ and $\beta 23$ interactive coefficients. $\mathrm{A}, \mathrm{B}$ and $\mathrm{C}$ were the independent variables corresponding to the concentration of $\mathrm{CuSO}_{4}$, guaiacol and wheat bran respectively.

Statistical analysis of the model was performed to evaluate the analysis of variance (ANOVA) and the quadratic models were represented as contour plots (3D) using Design-
Expert $^{\circledR} 8$ software from Stat-Ease, Inc. Poojary and Mugeraya (2012).

Table 4: Analysis of variance (ANOVA) for response surface quadratic model.

\begin{tabular}{cccccc}
\hline Source & $\begin{array}{c}\text { Sum of } \\
\text { Squares }\end{array}$ & df & $\begin{array}{c}\text { Mean } \\
\text { Square }\end{array}$ & F-value & $\begin{array}{c}\text { P-value } \\
\text { Prob }>\text { F }\end{array}$ \\
\hline Model & 4069.65 & 1 & 452.18 & 41.41 & $<0.0001$ significant \\
A-CuSO4 & 4.97 & 1 & 4.97 & 0.46 & 0.5152 \\
B-Guaiacol & 141.22 & 1 & 141.22 & 12.93 & 0.0049 \\
C-Wheat bran & 3461.52 & 1 & 3461.52 & 317.04 & $<0.0001$ \\
AB & 110.86 & 1 & 110.86 & 10.15 & 0.0097 \\
AC & 66.59 & 1 & 66.59 & 6.10 & 0.0331 \\
BC & 57.03 & 1 & 57.03 & 5.22 & 0.0454 \\
A $^{2}$ & 157.19 & 1 & 157.19 & 14.40 & 0.0035 \\
B $^{2}$ & 91.87 & 1 & 91.87 & 8.41 & 0.0158 \\
C $^{2}$ & 3.41 & 1 & 3.41 & 0.31 & 0.5884 \\
Residual & 109.18 & 10 & 10.92 & & \\
Lack of Fit & 108.81 & 5 & 21.76 & 289.01 & $<0.0001$ significant \\
Pure Error & 0.38 & 5 & 0.075 & & \\
Cor Total & 4178.83 & 19 & & & \\
R2 = 0.9739, Adj-R2 $=0.9504$, Pred-R2=0.8021, Std. Dev.= 3.30, Mean= \\
61.21, C.V. \%= 5.
\end{tabular}

\section{In vitro decolorization experiments}

Two chemically different synthetic dyes: Congo red and Crystal violet were tested in the following study at two different concentrations 50 and $100 \mathrm{ppm}$.

Cultivation on solid media was carried out in Petri dishes (90 mm diameter) containing N-limited Kirk medium (Tien and Kirk, 1988) with the respective dye at the two different concentrations. The dishes were inoculated with mycelial plugs (10 $\mathrm{mm}$ diameter) cut from actively growing mycelia and incubated at $28^{\circ} \mathrm{C}$ in dark for 7 days.

The culture filtrate with laccase activity was used as a source of enzymes to test its efficiency in decolorization of dyes. This was carried out by incubating high concentration (64.29 U) and low concentration $(27.55 \mathrm{U})$ of the enzyme in holes of agar plates supplemented with 50 and $100 \mathrm{ppm}$ of the respective dyes for $24 \mathrm{~h}$. The plates incubated under the same conditions.

\section{RESULTS AND DISCUSSION}

\section{Identification of the microorganism and guaiacol oxidation}

The marine-derived fungus used in the present study was identified taxonomically by molecular and conventional methods. Data derived from morphology, and phylogenetic analyses identified it as Alternaria tenuissima KM651985 with 99\% similarity Fig. (1\&2)

Initial experiments concerning laccase enzyme production in two different fermentation media. B\&K synthetic culture medium, which showed about $(7.12 \pm 2.73 \mathrm{U} / \mathrm{ml})$ and wheat bran natural culture medium $(14.51 \pm 3.41 \mathrm{U} / \mathrm{ml})$. These results indicated that the natural medium containing wheat bran was the most favorable as basal medium for laccase production. These results are consistent with our previous published work (Abd El Aty and Mostafa, 2013; Mostafa and Abd El Aty, 2013) where we found that wheat bran has a very strong potential for laccase production on comparison with other agro industry wastes. 
The positive effect of using wheat bran may be due to its components. The wheat bran is a byproduct of the wheat processing industry usually composed of non-starch polysaccharides ( $\alpha$ - arabinoxylans, cellulose and $\beta$-(1,3) 1,4-glucan), lignin, starch and crude protein (Songulashvili et al., 2011).

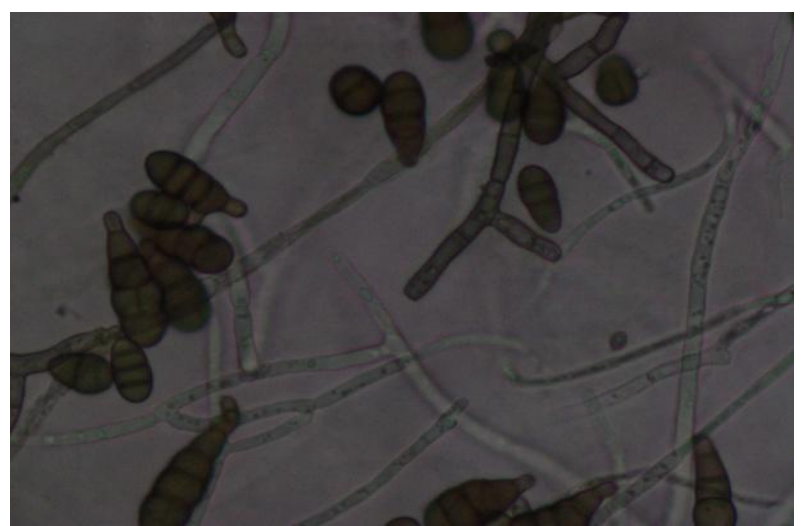

Fig. 1: Photo of A. tenuissima KM651985 conidia (different shapes and sizes) under microscope.

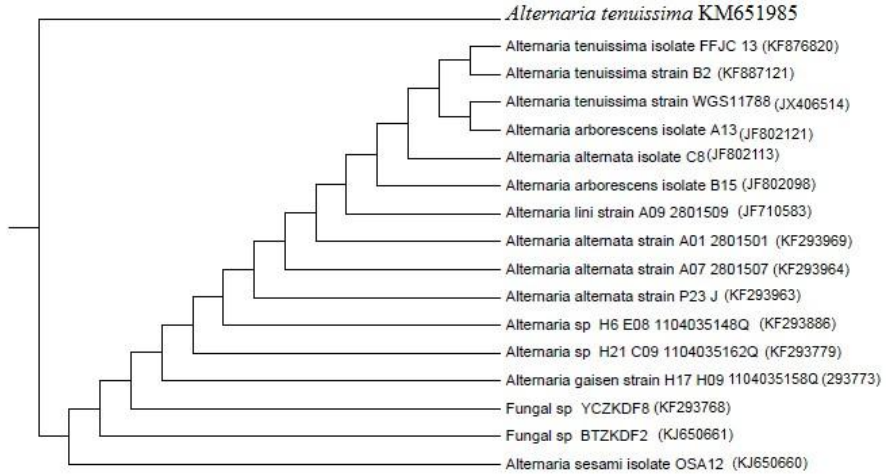

Fig. 2: Phylogenetic tree based on $18 \mathrm{~S}$ rRNA gene sequences showing closest relatives. Gen Bank sequence accession numbers are indicated in parentheses after the strain names.

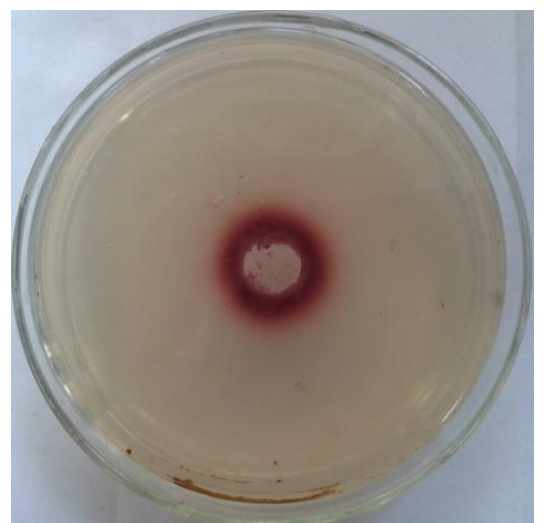

Fig. 3: Reddish brown zone formed around a pore containing (10.16 U of crude enzyme) after $24 \mathrm{~h}$ at $28{ }^{\circ} \mathrm{C}$ in dark, this colour is due to the oxidative polymerization of guaiacol by A. tenuissima KM651985 laccase enzyme.

When this culture filtrate added to $\mathrm{B} \& \mathrm{~K}$ plates supplemented with $4 \mathrm{mM}$ guaiacol, a reddish brown zone formed around a hole containing crude enzyme, due to the oxidative polymerization of guaiacol by A. tenuissima KM651985 laccase enzyme Fig. (3).

\section{Statistical optimization of laccase production.}

Two statistical designs were used for the optimization of medium components for laccase production.

\section{Plackett-Burman design (PBD)}

The medium components and inducers that are significantly influence A. tenuissima KM651985 laccase were determined by applying Plackett-Burman.

PB design experiments showed that, there were variations ranging from $1.3 \pm 0.497 \mathrm{U} / \mathrm{ml}$ to $45.5 \pm 2.486 \mathrm{U} / \mathrm{ml}$ in the production of laccase in 12 runs Table (1). This variation between obtained units reflected the importance of medium optimization to attain maximum yields.

Results obtained in the Pareto chart Fig. (4) showed the order of significance for the variables affecting laccase production. Among these variables, the inducers copper sulphate and guaiacol showed the highest significance by showing higher positive effect, followed by wheat bran, veratryl alcohol and glucose. Ammonium tartarate, phenol, ABTS and peptone contributed negatively.
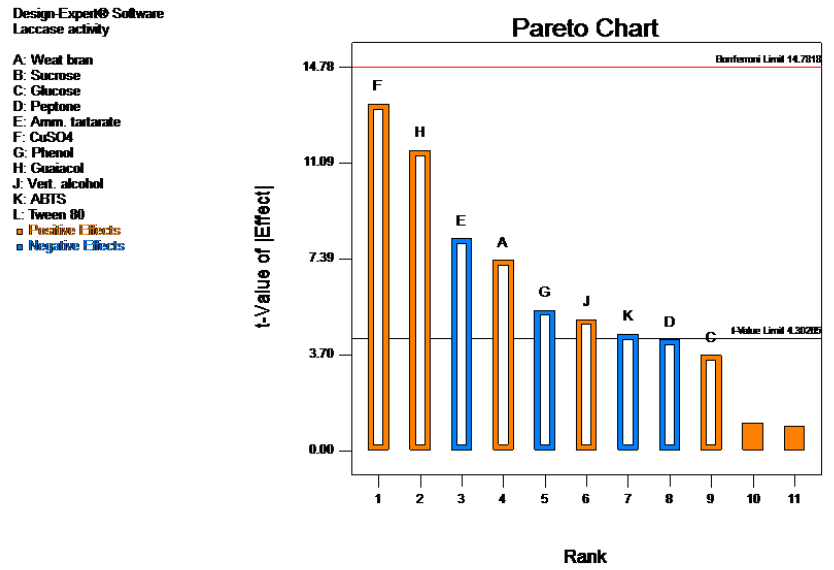

Fig. 4: Pareto chart of eleven-factor standard effects on laccase production.

The positive effect of copper sulphate in our research is in agreement with previous published results (Galhaup and Haltrich, 2001; Shutova et al., 2008; Zhang et al., 2012). The $\mathrm{Cu}^{2+}$ is an extremely important metal ion and could induce laccase secretion. The role of $\mathrm{Cu}^{2+}$ may be due to its induction effect on transcription of the laccase gene (Galhaup et al., 2002). Another reason is that $\mathrm{Cu}^{2+}$ may be buried at the catalytic center and maintains the stability of the laccase. Also D'Souza et al. (2006) indicated that, $\mathrm{CuSO}_{4}$ and guaiacol induced the maximum laccase production by the marine fungal isolate, NIOCC \# 2a, individually as well as in combination.

According to the obtained results, the components of the following medium is expected to be near optimum: wheat bran 10 $\mathrm{g} / \mathrm{l}$, glucose $5 \mathrm{~g} / \mathrm{l}$, ammonium tartarate $0.2 \mathrm{~g} / \mathrm{l}$, peptone $0.2 \mathrm{~g} / \mathrm{l}$ and veratryl alcohol $1 \mathrm{mM}$, with addition of copper sulphate $2 \mathrm{mM}$ and 
guaiacol $1 \mathrm{mM}$ after 6 days of incubation, in $250 \mathrm{ml}$ Erlenmeyer flasks for 14 day incubation period. The enzyme activity measurement on this medium was $45.5 \pm 2.486 \mathrm{U} / \mathrm{ml}$. This result presented about 3.14-folds increase in the enzyme activity, when compared to $(14.51 \pm 3.41 \mathrm{U} / \mathrm{ml})$, the results obtained in basal production medium containing only wheat bran and sea water.

The analysis of variance (ANOVA) for the experiment design showed that, The Model F-value of 60.02 implies the model is significant. Values of "Prob > F" less than 0.0500 indicate model terms are significant. In this case A, E, F, G, H, J, K are significant model terms. Values greater than 0.1000 indicate that the model terms are not significant. The "Pred R-Squared" of 0.8672 is in reasonable agreement with the "Adj R-Squared "of 0.9797. "Adeq Precision" measures the signal to noise ratio, a ratio greater than 4 is desirable. Our ratio of 24.396 indicates an adequate signal. This model can be used to navigate the design space. Table (2). The first order model equation developed by PB design showed the dependence of laccase production on the medium constituents:

$\mathrm{R} 1$ (laccase activity $\mathrm{U} / \mathrm{ml})=+13.06+4.11 * \mathrm{~A}+2.06 * \mathrm{C}-2.39 * \mathrm{D}-$ $4.57 * \mathrm{E}+7.48 * \mathrm{~F}-3.03 * \mathrm{G}$

$+6.47 * \mathrm{H}+2.82 * \mathrm{~J}-2.51 * \mathrm{~K}$

Therefore, the optimum combination of the variables (copper sulphate, guaiacol and wheat bran) which had the highest significant influence on laccase production was further analyzed by central composite design of response surface methodology. Other variables with less significant effect were not included in the next optimization experiment, but instead were used in all trials at their (-1) level and (+1) level, for the negatively contributing variables and the positively contributing variables, respectively.

\section{Response Surface Methodology (RSM)}

According to PB design, copper sulphate, guaiacol and wheat bran were further applied for optimization using RSM. A central composite design (CCD) was employed within a range of $\alpha(-1.68)$ and $+\alpha(+1.68)$ in relation to laccase production to examine the combined effect of factors tested. The results presented in Table (3) showed the predicted and observed responses along with design matrix, the minimum response of $35.23 \mathrm{U} / \mathrm{ml}$ laccase activity was obtained with $4 \mathrm{mM}$ copper sulphate, $3 \mathrm{mM}$ guaiacol and $20 \mathrm{~g} / \mathrm{l}$ wheat bran. The maximum response of $91.84 \mathrm{U} / \mathrm{ml}$ laccase activity was obtained with $3 \mathrm{mM}$ copper sulphate, $2 \mathrm{mM}$ guaiacol and $46.82 \mathrm{~g} / \mathrm{l}$ wheat bran. These results indicated that, the high concentrations of copper sulphate and guaiacol were toxic for the fungus, while increasing the wheat bran concentration makes the medium near to semi-solid fermentation which is more useful for maximum laccase production. Wheat bran supply microorganisms with, zinc, hemicellulose, protein, manganese, iron and copper where its consider as a type of nutrient-richer by product of the wheat processing industry (Kalogeris et al., 2003; Oberoi et al., 2010), Wheat bran was also used for laccase production by (Marques de Souza et al., 2002) and Fomes sclerodermeus (Papinutti et al., 2003). The levels of laccase activity as a function of copper sulphate, guaiacol and wheat bran can be presented in terms of coded factors as in the following second-order regression equation: laccase activity $(\mathrm{U} / \mathrm{ml})=+65.52-0.60 * \mathrm{~A}+3.22 * \mathrm{~B}+15.92 * \mathrm{C}-$ $3.72 * \mathrm{~A} * \mathrm{~B}+2.89 * \mathrm{~A} * \mathrm{C}+2.67 * \mathrm{~B} * \mathrm{C}-3.30 * \mathrm{~A} 2 \quad-2.52 * \mathrm{~B} 2-0.49 * \mathrm{C} 2$ F-test and analysis of variance for response surface quadratic model is shown in Table (4), which confirmed the statistical significance of the equation. ANOVA of regression model demonstrates that the model is highly significant as it is evident from the Fischer test with very low probability value. The value of lack of fit, Model F and model P>F were found to be 289.01, 41.41 and $<0.0001$ respectively, indicating that model was significant. The coefficient of regression $\left(\mathrm{R}^{2}\right)$ was calculated to be 0.9739 indicating the goodness of fit of the model. The adjusted regression coefficient (Adj $R^{2}=0.9504$ ) was also high, showed for high significance of the model. Low coefficient variation $(\mathrm{CV}=5.40 \%)$ confirm the reliability of the experimental design.

In this case $\mathrm{B}, \mathrm{C}, \mathrm{AB}, \mathrm{AC}, \mathrm{BC}, \mathrm{A} 2, \mathrm{~B} 2$ are significant model terms where "Prob $>\mathrm{F}$ " less than 0.0500 . On the other hand $\mathrm{A}, \mathrm{C}^{2}$ seems to be insignificant where "Prob $>\mathrm{F}^{\text {" greater than }}$ 0.1000 , which doesn't affect the model and can be removed. The three dimensional (3D) response surface plots of the three factors are showed in Fig. (5).
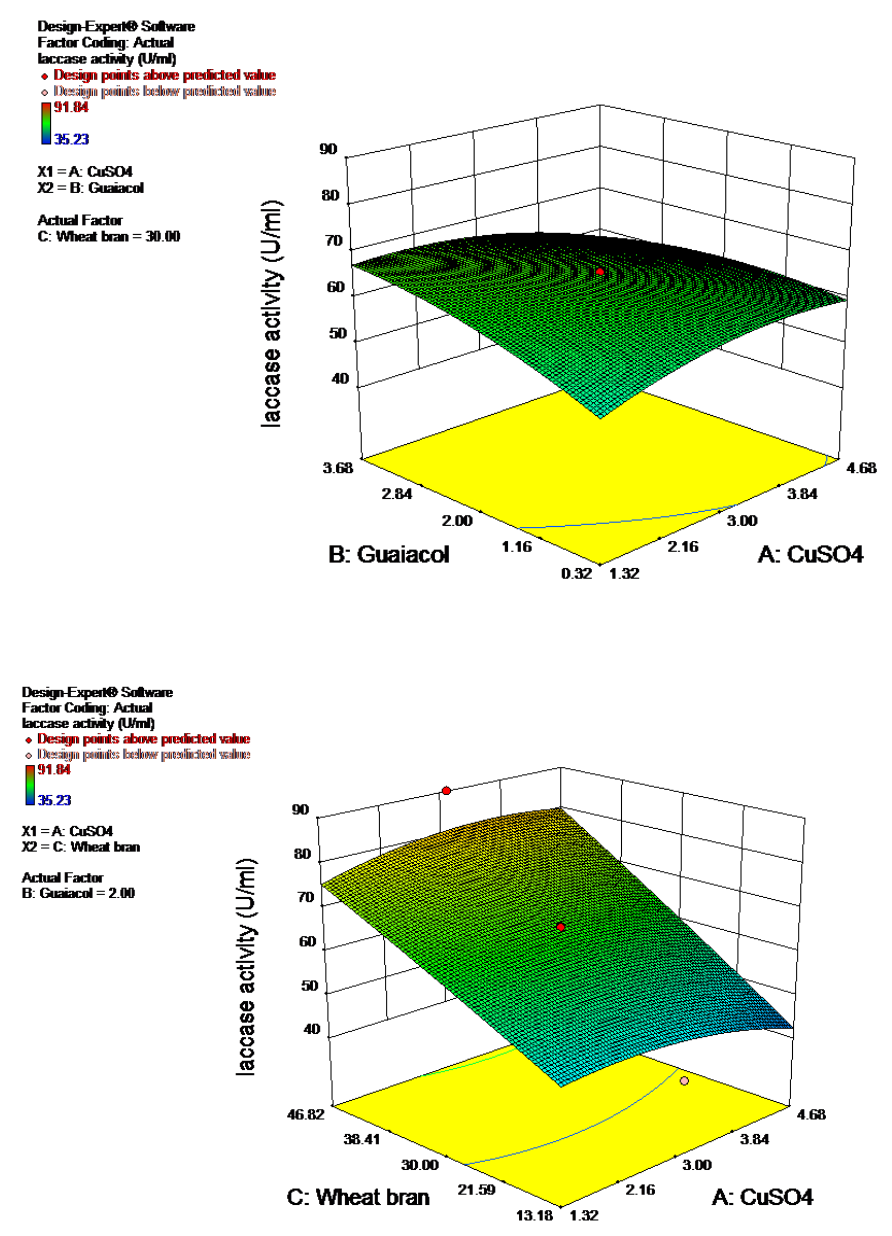


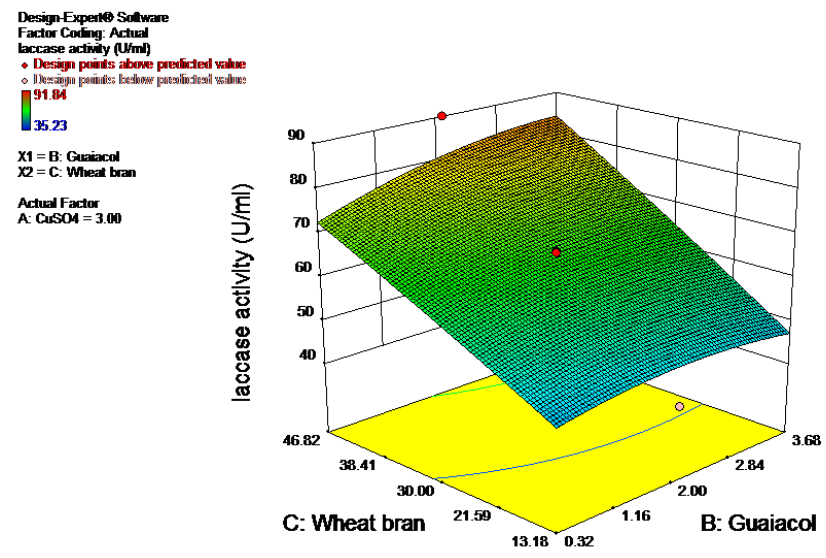

Fig. 5: Three dimensional response surface plot for the effect of (a)copper sulphate and guaiacol, (b) wheat bran and copper sulphate, (c) wheat bran and guaiacol.

The validation was carried out under the following optimum conditions of the medium. Wheat bran $46.82 \mathrm{~g} / \mathrm{l}$, glucose $5 \mathrm{~g} / \mathrm{l}$, ammonium tartarate $0.2 \mathrm{~g} / \mathrm{l}$, peptone $0.2 \mathrm{~g} / \mathrm{l}$ and veratryl alcohol $1 \mathrm{mM}$, with addition of copper sulphate $3 \mathrm{mM}$ and guaiacol $2 \mathrm{mM}$ after 6 days of incubation, in $250 \mathrm{ml}$ Erlenmeyer flasks at $28{ }^{\circ} \mathrm{C}$ for 14 day incubation period.

The experimental laccase production of $91.84 \mathrm{U} / \mathrm{ml}$ was obtained which is closer to the predicted laccase production of $90.92 \mathrm{U} / \mathrm{ml}$. This result indicated the validity and the effectiveness of the proposed model. The production of laccase by A. tenuissima KM651985 at the optimized conditions is much higher than that produced by the Brazilian marine-derived Aspergillus sclerotiorum CBMAI 849 (13.9 U/L), Cladosporium cladosporioides CBMAI 857 (203.70 U/L) and Mucor racemosus CBMAI 847 (898.15U/L) (Bonugli-Santos et al., 2010).

It was obvious that, optimization of $\mathrm{CCD}$ resulted in 6.33-fold increase in laccase production. This reflects the necessity and value of optimization process. There is no report available on statistical optimization of the marine-derived A. tenuissima KM651985 laccase enzyme by using PBD and RSM, most reports available so far are on optimization of laccase by using white rot fungi (Poojary and Mugeraya, 2012; Zhang et al., 2012).

\section{Application to synthetic dyes decolorization}

Results of experiment I showed the ability of the marinederived A. tenuissima KM651985 to grow and decolorize the two structurally different (Azo and triphenylmethane) synthetic dyes on solid media at 50 and $100 \mathrm{ppm}$ concentrations with different rates after 7 days, as shown in Table (5) and Fig. (6, A\&B). A positive correlation between the radial growth and the decolorization rate was found. Congo red, azo dye used in textile industries, decolorized almost completely by the marine-derived $A$. tenuissima KM651985 after 14 days incubation. The results are nearly consistent with the reports of Mtui and Nakamura (2008) and Yang et al. (2003) that demonstrate significant decolorization of aromatic dyes by Flavodon flavus and terrestrial fungi while
Raghukumar (2005) reported the same trends for facultative marine fungi.

Table 5 : Decolorization of synthetic dyes by the marine-derived $A$ tenuissima KM651985 and its crude enzyme on solid medium.

\begin{tabular}{|c|c|c|c|c|}
\hline \multirow{2}{*}{$\begin{array}{l}\text { Type of Dye } \\
\text { and used } \\
\text { concentration } \\
(\text { ppm })\end{array}$} & \multicolumn{2}{|c|}{ Experiment $I^{*}$} & \multicolumn{2}{|c|}{$\begin{array}{c}\text { Experiment II } \\
\text { Decolorization zone } \\
\text { diameter }(\mathbf{m m})\end{array}$} \\
\hline & $\begin{array}{c}\text { Fungal } \\
\text { colony } \\
\text { diameter } \\
(\mathbf{m m})\end{array}$ & $\begin{array}{c}\text { Decolorization } \\
\text { zone diameter } \\
(\mathbf{m m})\end{array}$ & $\begin{array}{c}\text { Low } \\
\text { enzyme } \\
\text { conc. } \\
(\mathbf{m m}) \\
\end{array}$ & $\begin{array}{c}\text { High } \\
\text { enzyme } \\
\text { conc. } \\
(\mathrm{mm})\end{array}$ \\
\hline \multicolumn{5}{|l|}{ Congo Red } \\
\hline 50 & 45.0 & 75.0 & 26.5 & 32.0 \\
\hline 100 & 37.5 & 50.0 & 20.0 & 25.0 \\
\hline \multicolumn{5}{|l|}{ Crystal Violet } \\
\hline 50 & 20.0 & 29.0 & - & 22.0 \\
\hline 100 & 15.0 & 21.0 & - & - \\
\hline
\end{tabular}

Experiment I: Radial growth rate measured as a diameter of mycelial colony and decolorization measured as a diameter of decolorized zone on a Petri dish on the 7th day of cultivation on Kirk N-limited medium containing 50 and 100 ppm of the respective dyes ${ }^{* * *}$ Experiment II: Decolorization rate of two different concentrations of the crude enzyme measured as a diameter of decolorized zone around the hole on a Petri dish containing agar supplemented with 50 and $100 \mathrm{ppm}$ of the respective dyes after 24h. (All the plates incubated at $28^{\circ} \mathrm{C}$ in dark).
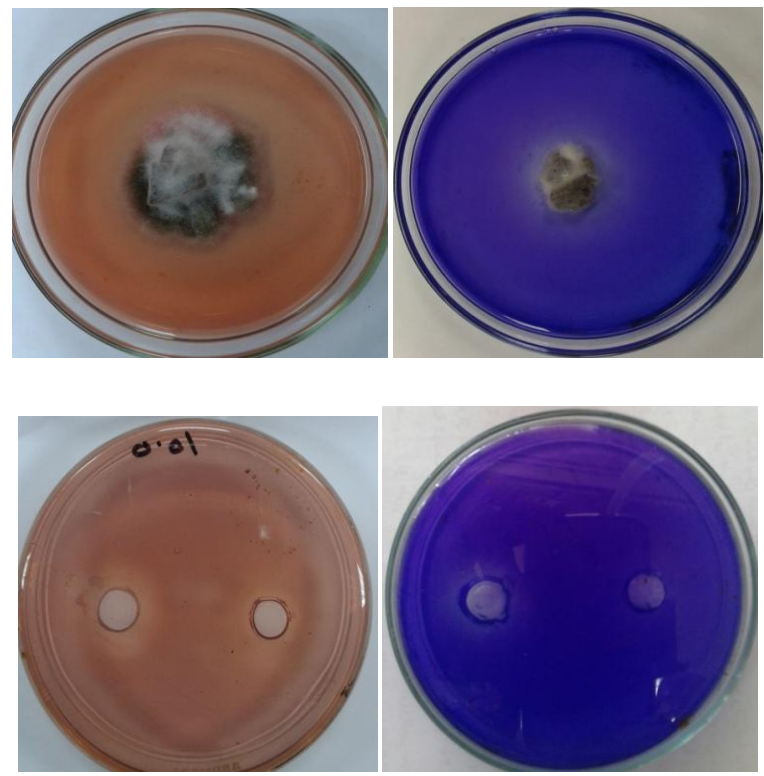

Fig. 6: A, decolorization of congo red (100 ppm) by A. tenuissima KM651985. $\mathrm{B}$, decolorization of crystal violet (50 ppm) by A. tenuissima KM651985. C, decolorization of congo red by high (1) and low (2) concentrations of the crude enzyme. D, decolorization of crystal violet by high (1) and low (2) concentrations of the crude enzyme.

Also Saparrat et al. (2008) indicated that, the white-rot fungus Grammothele subargentea LPSC no. 436, was able to degrade $0.01 \%$ (100 ppm) of congo red more efficiently and in time less than taken for crystal violet. According to that mentioned by Parawira and Tekere (2013), the simple not very pure preparation of enzymes is more useful and economic for industrial applications of laccases. Therefore, crude A. tenuissima KM651985 laccase enzyme was used to decolorize the tested dyes at two different concentrations in experiment II. 
As shown in Table (5), significant differences were obtained, depending on the dye and crude enzyme concentrations. Crystal violet exhibited the least decolorization efficiency, while the azo dye congo red showed relatively high decolorization efficiency after $24 \mathrm{~h}$ Fig. (6, C\&D).

\section{CONCLUSION}

The first goal of the search in finding the optimum conditions for laccase production by the marine-derived $A$. tenuissima KM651985 has been achieved by the combination of Plackett-Burman design and central composite design. Wheat bran can be used as substrate to produce laccase by A. tenuissima KM651985 decreasing the concentration of glucose level in the medium to $5 \mathrm{~g} / \mathrm{l}$. This is an economical and environment friendly way to reuse agricultural residues. In addition, copper sulphate and guaiacol as inducers have a positive effect and play a major role on laccase formation. A. tenuissima KM651985 was able to decolorize efficiently two different synthetic dyes, congo red and crystal violet on agar plates by mycelium plugs and by crude enzyme without any mediators. This is the first report on the applications of the marine-derived A. tenuissima KM651985 in dyes decolorization. This encourage further research for bioremediation of lignin-based derivatives and colored industrial pollutants that are alkaline and have high salt concentrations.

\section{CONFLICT OF INTERESTS}

The authors declare that there is no conflict of interests regarding the publication of this paper.

\section{ACKNOWLEDGEMENTS}

This work was financially supported by Department of Chemistry of Natural and Microbial Products, National Research Centre, Cairo, Egypt, project number 10070213.

\section{REFERENCES}

Abd El Aty AA, Mostafa FA. Effect of various media and supplements on laccase activity and its application in dyes decolorization. Malaysian Journal of Microbiology, 2013; 9: 166-175.

Abd El Aty AA, El-Shamy AR, Atalla SMM, El-Diwany AI, Hamed ER. Screening of Fungal Isolates for Laccase Enzyme Production from Marine Sources. Research Journal of Pharmaceutical, Biological and Chemical Sciences, 2015; 6: 221-228.

Altschul SF, Madden TL, Schaffer AA, Zhang JH, Zhang Z, Miller W, Lipman, DJ. Gapped BLAST and PSI-BLAST: a new generation of protein database search programs. Nucleic Acids Research, 1997; 25: 3389-3402.

Bartlett RE. Public Health Engineering-Design in Metric WasteWater treatment. London: Applied Science Publishers, 1971.

Bhattacharya SS, Garlapati VK, Banerjee R. Optimization of laccase production using response surface methodology coupled with differential evolution. New Biotechnol, 2011; 28: 31-39.

Bonugli-Santos RC, Durrant LR, da Silva M, Sette LD. Production of laccase, manganese peroxidase and lignin peroxidase by Brazilian marine-derived fungi. Enzyme and Microbial Technology, 2010; 46: 32-37.
Bournnais R, Paice MG, Reid ID, Lanthier P, Yaguchi M. Lignin oxidation by laccase isoenzymes from Trametes versicolor. Appl. Environ Microbiol, 1995; 61: 1876-1880.

Bucher VVC, Hyde KD, Pointing SB, Reddy CA. Production of wood decay enzymes, mass loss and lignin solubilization in wood by marine ascomycetes and their anamorphs, Fungal Diversity, 2004; 15: 114.

D’Souza DT, Tiwari R, Sah AK, Raghukumar C. Enhanced production of laccase by a marine fungus during treatment of colored effluent and synthetic dyes. Enzyme and Microbial Technology, 38; 2006: 504-511.

Galhaup C, Haltrich D. Enhanced formation of laccase activity by the white-rot fungus Trametes pubescens in the presence of copper Appl Microbiol Biotechnol, 2001; 56: 225-232.

Galhaup C, Goller S, Peterbauer CK, Strauss J, Haltrich D. Characterization of the major laccase isoenzyme from Trametes pubescens and regulation of its synthesis by metal ions. Microbiology, 2002; 148 : 2159-2169.

Giardina P, Faraco V, Pezzella C, Piscitelli A, Vanhulle S, Sannia G. Laccases: a never-ending story. Cell Mol. Life Sci, 2010; 67: 369-385.

Höller U, König GM, Wright AD. A new tyrosin kinase inhibitor from a marine isolate of Ulocladium botrytis and new metabolites from the marine fungi Asteromyces cruciatus and Varicosporina ramulosa. Eur J Org Chem, 1999; 2949-2955.

Kalogeris E, Iniotaki F, Topakas E, Christakopoulos P, Kekos D, Macris BJ. Performance of an intermittent agitation rotating drum type bioreactor for solid-state fermentation of wheat straw. Bioresour Technol, 2003; 86: 207.

Kohlmeyer J, Kohlmeyer E. 1979. Marine Mycology-The Higher Fungi, Academic Press, New York: San Francisco; London.

Marques de Souza CG, Zilly A, Peralta RM. Production of laccase as the sole phenoloxidase by a Brazilian strain of Plerotus pulmonarius in solid state fermentation. J Basic Microb, 2002; 42: 83-90.

Morozova OV, Shumakovich GP, Gorbacheva MA, Shleev SV, Yaropolov AI. "Blue" laccases. Biochemistry Mosc, 2007; 72: 11361150.

Mostafa FA, Abd El Aty AA. Enzyme activities of the marinederived fungus Alternaria alternata cultivated on selected agricultural wastes. Journal of Applied Biological Sciences, 2013; 7: 3946.

Mtui G, Nakamura Y. Lignocellulosic enzymes from Flavodon flavus, a fungus isolated from Western Indian Ocean off the coast of Dar es Salaam, Tanzania. African Journal of Biotechnology, 2008; 7: 30663072 .

Oberoi HS, Chavan Y, Bansal S, Dhillon GS. Production of Cellulases through Solid State Fermentation Using Kinnow Pulp as a Major Substrate. Food and Bioprocess Technol, 2010; 3: 528.

Osma JF, Toca-Herrera JL, Rodriguez-Couto S. Transformation pathway of Remazol Brilliant Blue R by immobilised laccase, Bioresour Technol, 2010; 101: 8509-8514.

Papinutti VL, Diorio LA, Forchiassin F. Production of laccase and manganese peroxidase by Fomes sclerodermeus grown on wheat bran. J Ind Microb Biotechnol, 2003; 30: 157-160.

Parawira W, Tekere M. Biotechnological strategies to overcome inhibitors in lignocellulose hydrolysates for ethanol production: review, Crit. Rev. Bio-technol, 2011; 31: 20-31.

Pitt JI, Hocking AD. 1985. Fungi and food spoilage. Academic Press (Pub.) Sydney, New York: London.

Plackett Rl, Burman JP. The design of optimum multifactorial experiments, Biometrika, 1946; 37: 305-325.

Pointing SB, Hyde KD. Lignocellulose-degrading marine fungi. Biofouling, 2000; 15: 221-229.

Poojary H, Mugeraya G. Laccase Production by Phellinus noxius $h p$ F17: Optimization of Submerged Culture Conditions by Response Surface Methodology, Research in Biotechnology, 2012; 3: 0920. 
Raghukumar C. Marine fungi and their enzymes for decolorization of coloured effluents. In: Ramiah, N. (ed). Marine lignolytic fungi, Natl. Inst. Oceanogr, GOA, 2005; 145-158.

Rodriguez CS, Sanroman M, Gubitz GM. Influence of redox mediators and metal ions on synthetic acid dye decolourization by crude laccase from Trametes hirsute. Chemosphere, 2005; 58: 417-422.

Saparrat MCN, Mocchiutti P, Liggieri CS, Aulicino MB, Caffini NO, Balatti PA; Martínez MJ. Ligninolytic enzyme ability and potential biotechnology applications of the white-rot fungus Grammothele subargentea LPSC no. 436 strain. Process Biochemistry, 2008; 43: 368375 .

Shervedani RK, Amini A. Direct electrochemistry of dopamine on gold-Agaricus bisporus laccase enzyme electrode: Characterization and quantitative detection. Bioelectrochemistry, 2012; 84: 25-31.

Shutova VV, Revin VV, Makushina YA. The effect of copper ions on the production of laccase by the fungus Lentinus (Panus) tigrinus, Prikl Biokhim Mikrobiol, 2008; 44: 683-687.

Songulashvili G, Jimenéz-Tobón G, Jaspers C, Penninckx MJ. High production of laccase by Ganoderma lucidum 447 in submerged cultivation on ethanol production residue supplemented with $\mathrm{Cu} 2+$. Mycosphere, 2011; 2: 507-513.

Tien M, Kirk TK. Lignin peroxidase of Phanerochaete chrysosporium. Methods Enzymol, 1988; 161: 238-248.
White TJ, Bruns T, Lee S, Taylor JW. 1990. Amplification and Direct Sequencing of Fungal Ribosomal RNA Genes for Phylogenetics. In: PCR Protocols: A Guide to Methods and Applications. Academic Press, San Diego. California: USA 315-322.

Yang QY, Yang M, Pritsch K, Yediler A, Hagn A, Scloter M, Kettrup A. Decolorization of synthetic dyes and production of manganesedependent peroxidases by new fungal isolates. Biotechnol Lett, 2003; 25: 701-713.

Zhang Y, Sun S, Hu K, Lin X. Improving production of laccase from novel basidiomycete with response surface methodology. African Journal of Biotechnology, 2012; 11: 7009-7015.

\section{How to cite this article:}

Abd El Aty AA, Hamed ER, El-Beih AA, El-Diwany AI. Induction and enhancement of the novel marine-derived Alternaria tenuissima KM651985 laccase enzyme using response surface methodology. Application to Azo and Triphenylmethane dyes decolorization. J App Pharm Sci, 2016; 6 (04): 006-014. 